\title{
MATHEMATICAL MODEL FOR SCHEDULING IRRIGATION FOR SWAMP RICE IN PORT HARCOURT L.G.A, NIGERIA
}

\author{
U. J. CHIWETALU, M. J. AYOTAMUNO AND E. A. OBIO
}

(Received 24 March 2017; Revision Accepted 8 June 2017)

\begin{abstract}
The thirst for increased food production and management of our natural resources (water) is increasing on daily basis and there is a great need for proper utilization of such important resource. Nigerian farmers today still rely on rainfall for cultivation of food crops, this is simply because they do not have the knowledge of irrigation scheduling and timing and it has affected the rate at which food crops are produced in our country. The formula of a mathematical model that can predict the required amount of irrigation water for swamp rice in Port Harcourt L.G.A. of Nigeria was the main objective of this work. Thus, the formula or the model is given as; $d_{2}=d_{1}+E_{R F}+I+I_{p}-E T_{c}$. The maximum and minimum values of water depth $\left(d_{\max }\right.$ and $\left.d_{\min }\right)$ required in the field were determined to be $320.32 \mathrm{~mm}$ and $160 \mathrm{~mm}$ respectively. The result showed that, the model was able to augment the water need of the planted crop except in weeks 5 and 6 which have the values of $d_{2}$ (final water depth in the field) as $135.69 \mathrm{~mm}$ and $120.07 \mathrm{~mm}$ respectively. While the mother model indicated that the planted crops will be under severe water stress because the values of their $\mathrm{d}_{2}$ were below the allowable range of water depletion except in weeks $1,7,10,16$ and 17 with their $d_{2}$ values to be; $178.50 \mathrm{~mm}, 181.47 \mathrm{~mm}, 162.11 \mathrm{~mm}, 198.80 \mathrm{~mm}$ and $187.60 \mathrm{~mm}$ respectively. Water application is made on the field whenever the water level is at or below $d_{\min }$. The result of the correlation analysis for the two models was obtained to be 0.002796 . This showed that the two models have a strong non linear relationship between them.
\end{abstract}

KEYWORDS: Mathematical model, irrigation, Water, swamp rice

\section{Terminology}

ETc - Crop evapotranspiration $(\mathrm{mm})$

$\mathrm{E}_{\mathrm{RF}}$ - Effective rainfall (mm)

$\mathrm{ET}_{0}$ - Reference crop evapotranspiration ( $\left.\mathrm{mm}\right)$

RF - Rainfall (mm)

$I_{P}-$ Required pounding depth $(\mathrm{mm})$

I - Irrigation water applied (mm)

$\mathrm{d}_{1}$ - Initial depth of water in the field $(\mathrm{mm})$

$\mathrm{d}_{2}$ - Initial depth of water in the field $(\mathrm{mm})$

$\mathrm{Kc}$ - Crop factor

$\mathrm{Mc}$ - Soil moisture content $(\mathrm{mm})$

PwP - Permanent wilting point (mm)

\section{INTRODUCTION}

Rice is a food crop universally accepted and eaten all over the world. It is the most

important staple food for about half of the human race (Hawksworth, 1985). It ranks third after wheat and maize in terms of production. The rate at which it is consumed resulted into finding ways

U. J. Chiwetalu, Agricultural and Bio-resource Engineering Department, Enugu State University of Science and Technology, P.M.B.01660, Enugu State, Nigeria.

M. J. Ayotamuno, Agricultural and Environmental Engineering Department, Rivers State University of Science and Technology, P.M.B.5080, Port Harcourt, Nigeria.

E. A. Obio, Agricultural and Environmental Engineering Department, Cross River University of Technology, Calabar, Cross River State, Nigeria. 
that will enhance the production of such a staple food. Production of every food is dependent upon water, though many other factors limit crop growth and yield (Ayotamuno et al., 2000). Rice like every other crop obtains their water from reserves of moisture stored in the soil root zone, which are replenished from time to time by either rain or irrigation. In local conditions, a reasonable degree of crop production is usually maintained by rainfall. However, this cannot always be relied upon for an ever increasing population of this generation and mostly when embarking on high level commercial production. This is because serious adverse effects of long spell of dry weather on crops are usually seen in their growth and yield which result into premature ripening of their fruits and sometimes complete crop failure.

Rice has different distinguishable physiological stages of growth beginning from the nursery stage to the maturity stage. The nursery stage of rice is the period of sowing to transplant. Its duration is about 25 to 30 days while vegetative stage begins from the period of transplant to the period of panicle initiation till flowering, the duration is about 30 day. Maturity stage starts from flowering to full ripening, the duration is about 30 days. Counce et al. (2000) introduced the Cumulative Leave Number (CLN) as a method of identifying the different stages of rice growth using the number of leaves produced by planted crop. Crop coefficients $(\mathrm{Kc})$ for rice have been determined by several researchers. Tyagi et al. (2000), determined the coefficient for kernel Indian rice to be; 1.15, 1.23, 1.14 and 1.02 for the four distinct stages of rice growth of initial, crop development, reproductive and maturity stage respectively. Tripathy (2004), obtained the crop coefficient for Tarai region of Uttaranchal, India as 0.39 at transplant, crop development, reproductive and maturity stage respectively. Shah et al. (1986) derived the crop coefficients of rice at vegetative, reproductive and maturity stages as $0.96,1.20$ and 1.17 respectively for central plain of Thailand. Tamor and O'toole (1980) found these values as 1.0, 1.15, 1.3 at transplant, maximum tillering stage and flowering stage respectively for both wet and dry season rice. Doorenbos and Pruitt (1984) suggested their values for both wet and dry seasons for different geographical locations which Nigeria is inclusive to be: $1.10,1.05$, and 0.95 for wet season and $1.25,1.10$, and 1.00 for dry season in Asia with light to moderate wind.

The demand for this staple food is increasing every day. Its cultivation requires a lot of water which in one or the other affects the availability of water for some other purposes. In our local environment, cultivation of crops is usually skewed towards rainfall season because of the two major distinct seasons. This automatically affects the rate of production of several food crops produced in the locality as meaningful production of food can only be achieved during rainy season period of year. However, this work aims at solving the problem of improper prediction of the amount of water required to irrigate a rice farm in order to avoid wastage of water during rice cultivation. It also solves the problem of food and water insecurity as well as improving the country's economic status as meaningful production of food crops can be achieved all through the year.

\subsection{METHODS}

\subsection{The Study Area}

The experimental study was conducted in Port Harcourt L.G.A. of Rivers State, Nigeria. The area lies on a longitude of $04^{\circ} .04 \mathrm{E}$ and $07^{\circ} .00 \mathrm{E}$ and latitude of $04^{\circ} .45^{\prime} \mathrm{N}$ and $07^{\circ} .00 \mathrm{~N}$ of the equator at $10 \mathrm{~m}$ altitude of sea level. The rainfall pattern is bimodal between April and October, while dry season is between November and March. It has high rainfall of about $3000 \mathrm{~mm}$ $3500 \mathrm{~mm}$ per annum. The area is deltaic in nature with high deposit of organic fertilizers after each flooding. The area in general, has a uniform flat topography, which enhances infiltrations and reduces surface runoff. Rivers State is located in south - south part of Nigeria with high mean annual temperature of $28.2^{\circ} \mathrm{C}$. The soil type dominant in the area is of fine texture and has a greater proportion of sand and loam than other soil particles and could be classified as loamy sand.

\subsection{Materials Used for the Study}

Rice samples, Faro variety is a high yielding semi-dwarf variety mainly for irrigated low land ecology. It is a popular variety of rice and was introduced in Nigeria since 1974 (Singh, 1997). This variety of rice can survive in different ecology in Nigeria. The crop period of this specie of rice is about 120 days and the crop was planted thus during the late period of raining season between November $17^{\text {th }}, 2008$ and March $16^{\text {th }}, 2009$. The water need of the plant was supplemented through irrigation.

\subsection{Data Collection Method}

This work made use of both primary and secondary data. The primary sources include; 
direct measurements, field survey and physical observations. Soil samples were collected with soil auger at random in the field at the depth of $15 \mathrm{~cm}$ in accordance with the effective rooting depth for shallow rooted crops which rice is inclusive (Borgs and Grimes, 1986). The samples were taken to the laboratory for moisture determination using gravimetric approach. This because of its level of accuracy and suitability for experimental works (Michael, 1978). Water levels in the field were also observed physically and measured throughout the whole interval of irrigation. Direct observation was also adopted in determining the crops that were pest and disease infected. Secondary information and data were also used in this work, which were obtained from published materials. This provided data on crop coefficient and required pounding depth for rice. Rainfall data, minimum and maximum temperature, day light per hour information were obtained from IITA (International Institute for Tropical Agriculture) Onne metrological station and Federal Ministry of Aviation, all in Port Harcourt, Rivers State, Nigeria in 2008 and 2009.

\subsection{Theory}

A mathematical model developed by Fubara (2006) from water balance equation for scheduling of irrigation in Niger Delta region of Nigeria was modified and used for this research. His model is thus stated as;

$d_{2}=d_{1}+E_{R F}+I-E t c$

Where;

$\mathrm{d}_{2}=$ soil moisture content at the end of a given interval of time

$\mathrm{d}_{1}=$ soil moisture content at the beginning of a given interval of time

$E_{\mathrm{RF}}=$ effective rainfall within the considered interval of time

I = the depth of irrigation water applied

$\mathrm{ETC}=$ crop evaporation

However, this equation or mathematical model can be used for maize and other crops except rice (swamp rice) that grows under pounded condition. In order to make the model (equation 1) suitable for cultivation of rice, it was modified to suit rice growth condition by introducing a variable Ip (required pounding). The new model is stated below as;

$d_{2}=d_{1}+E_{R F}+I+I_{p}-E T C$
Where;

$I_{p}=$ depth of pounded water on the field

Hence, equation (2) was used for this research as it gives the essential parameter for scheduling of irrigation for rice. The daily water need of rice in any rice field is the difference between the sum of the evapotranspiration losses and the quantity of water needed to raise the pounding depth from available water in the field, (Aminul et al., 2004). Thus, the useful part of the rain and the amount of water taken away by evaporation and transpiration were put into consideration while accounting for the crop water need at each interval of irrigation. Equation (3) below was used in the estimation of the water need of the crop before each irrigation interval. Given that

$\mathrm{I}=\mathrm{ET} \mathrm{C}_{\mathrm{C}}-\mathrm{ERF}$

Equation 2 becomes $d_{2}=d_{1}+I_{p} \ldots \ldots \ldots \ldots$

\subsection{Soil Moisture determination}

Soil moisture measurements are essential in scheduling of irrigations and estimation of the amount of water to apply in each interval of irrigation. Moisture content of the soil was determined in this work using the gravimetric approach of moisture determination. Soil samples were collected randomly in different locations of the farm with soil auger at the depth of $15 \mathrm{~cm}$ and put in an air tight container. Those samples were taken to the laboratory for moisture determination. The difference in weight of the soil before and after oven dryness is the moisture content for that particular soil sample. The field capacity is usually the upper limit of the soil $\left(\mathrm{d}_{\max }\right)$ which is $320.23 \mathrm{~mm}$ for loam soil and was taken as $d_{\max }$ for this work. However, there is no general acceptable limit or level to be taken as the lower limit of moisture depletion $\left(d_{\min }\right)$. A lower limit of $50 \%$ available water depletion $(160 \mathrm{~mm})$ was chosen for this work in accordance with the research conducted by Savage et al (1996) who along observed that plants cannot meet up with their evapotranspiration water demands, if their root zone extractable water is below $40 \%-50 \%$ depletion. Usually the moisture content of the soil is usually determined in percentage by weight and should be converted to volume basis before it is applicable to irrigation. It was determined using the equation below:

Mc $(\%$ by volume $)=M c(\%$ by weight $){ }^{*}$ Bulk density $\ldots$ 
On the other hand, the bulk density of the soil was determined by collecting an un-compacted soil sample of known volume and carefully trimming them at both side ends of the core cylinders and weighed. These samples were oven dried at temperature of $105^{\circ} \mathrm{C}$ for about 24 hours until all the moisture were driven off and the samples were weighed again. The volume of the soil at the core became the same with the volume of the core cylinder. Their weight in grams was divided by the volume of soil core which gave the bulk density

\subsection{Effective Rainfall}

Effective rainfall $\left(E_{R F}\right)$ is a term used to define that portion of rainfall that contributes to the water requirement of a growing crop in the field. Dastane (1978) defined effective rainfall to be the utilizable rainfall knowing well that rainfall is not necessarily useful at the time, rate or the amount received by the soil as some maybe lost by either deep percolation or surface runoff. However, computation of the effective rainfall was successfully achieved by the formular proposed by The Food and Agricultural Organization(FAO), (1986) shown in equation 5.

$E_{R F}=0.6 R F-10 O R P e=0.6 P-10$

Where:

$E_{\mathrm{RF}}=$ Effective Rainfall value

$\mathrm{RF}=$ Rainfall value

$\mathrm{P}_{\mathrm{e}}=$ Effective Precipitation

$\mathrm{P}=$ Precipitation

The equation 5 above was adopted in determining the effective part of the rain that fell during the stipulated period of time, simply because it is recommended when the measured precipitation within the stipulated irrigation interval is less than $75 \mathrm{~mm}$.

\section{7. $\quad$ Required Pounding Depth $\left(I_{p}\right)$}

The thickness of the pounded water on a rice field is an important factor to be considered for the growth of rice. Depth of pounded water on the field is usually allowed to fluctuate in the range from an upper limit to a lower limit. This can be determined using the equation below;

$I_{p}=d_{2}-d_{1}$

Equation 6 above was derived from equation (4) of this work, the parameters used here remained the same as explained in the previous equations 1 and 2 above.

\subsection{Time Interval}

The entire crop period of rice can be divided according to a number of intervals of time and each interval, further divided into subinterval of time according to required accuracy of calculation Zhaoyi (1984). However, the time interval chosen for irrigation in this work was seven days interval of water application in order not to subject the planted crop to water stress.

\subsection{Correlation Analysis}

The Pearson product moment correlation formula, Karl Pearson, (1980), was adopted in this study for the correlation of the results obtained from the two models.

$$
r=\frac{n\left(\sum x y\right)-\left(\sum x\right)\left(\sum y\right)}{\sqrt{\left[n \sum x^{2}-\left(\sum x\right)^{2}\right]\left[n \sum y^{2}-\left(\sum y\right)^{2}\right]}}
$$

Where;

$\mathrm{n}=$ number of pairs observed

$x=$ values of $d_{2}$ obtained from the model work of this study

$y=$ values of $d_{2}$ obtained from the model proposed by Fubara (2006)

\subsection{RESULTS AND DISCUSSION}

The results of this work were handled in two different ways:

\subsection{Results from secondary data}

These results were obtained from published materials and as well as from the Metrological Station at IITA, Onne and Ministry of Aviation all in Port Harcourt, Rivers state in the year $2008\left(17^{\text {th }}\right.$ November $-1^{\text {st }}$ December $)$ and $2009\left(1^{\text {st }}\right.$ January $-16^{\text {th }}$ March $)$. The values of the weekly rainfall (RF), crop potential evapotranspiration (ETo), crop factor (Kc) and the crop evapotranspiration (ETc) for the considered period of time are in Table (1). The highest rainfall during the crop growth period was $60.55 \mathrm{~mm}$, this was in week 16 . It could also be observed that, there was a break for about five weeks before the second rain during the considered period of time, the second rainfall was $40 \mathrm{~mm}$ per week. The weekly rainfall value obtained during the considered period of time simply indicated that it is highly impossible to rely 
on rainfall alone for cultivation of crops especially water loving crop like rice during the dry season period of the year in this locality. However, no meaningful crop production can take place in Port Harcourt L.G.A., Rivers State under rain fed agriculture during this period of this study, as the values of the rainfall obtained were very poor to sustain plant growth. Table 1 below, gives the input data (primary and secondary) used for the models.

Table 1: Primary and secondary data used for this work (input data) from Nov. $17^{\text {th }}, 2008-$ March $16^{\text {th }}$, 2009.

\begin{tabular}{|l|l|l|l|l|l|l|l|l|l|l|}
\hline Wks & $R F(m m)$ & $E_{\mathrm{RF}}(\mathrm{mm})$ & $\mathrm{Kc}$ & $\mathrm{ETo}(\mathrm{mm})$ & $\mathrm{d}_{1}(\mathrm{~mm})$ & $\mathrm{I}_{\mathrm{p}}(\mathrm{mm})$ & $\mathrm{I}(\mathrm{mm})$ & $\mathrm{Mc}(\mathrm{vol})$ & $\begin{array}{l}\text { Bulk } \\
\text { Density } \\
(\mathrm{g} / \mathrm{cc})\end{array}$ & $\mathrm{ETc}(\mathrm{mm})$ \\
\hline 1 & 31.65 & 08.99 & 8.039 & 5.638 & 178.50 & 50 & 36.32 & 17.85 & 1.41 & 45.324 \\
\hline 2 & 00.00 & 00.00 & 8.039 & 5.638 & 127.92 & 50 & 45.32 & 12.79 & 1.56 & 45.324 \\
\hline 3 & 00.00 & 00.00 & 8.242 & 5.762 & 098.75 & 50 & 47.49 & 09.88 & 1.58 & 47.490 \\
\hline 4 & 00.00 & 00.00 & 8.242 & 5.762 & 086.50 & 70 & 47.49 & 08.65 & 1.59 & 47.490 \\
\hline 5 & 00.00 & 00.00 & 8.242 & 5.762 & 065.69 & 70 & 47.49 & 06.57 & 1.61 & 47.490 \\
\hline 6 & 00.00 & 00.00 & 8.242 & 5.762 & 050.07 & 70 & 47.49 & 05.01 & 1.61 & 47.490 \\
\hline 7 & 40.00 & 14.00 & 7.733 & 5.451 & 181.47 & 70 & 28.15 & 18.15 & 1.41 & 42.153 \\
\hline 8 & 00.00 & 00.00 & 10.855 & 5.451 & 125.58 & 70 & 59.17 & 12.56 & 1.56 & 59.171 \\
\hline 9 & 19.75 & 01.85 & 10.855 & 5.451 & 149.15 & 70 & 57.32 & 14.91 & 1.49 & 59.171 \\
\hline 10 & 19.75 & 01.85 & 10.855 & 5.451 & 162.11 & 70 & 57.32 & 16.21 & 1.49 & 59.171 \\
\hline 11 & 00.00 & 00.00 & 11.699 & 5.762 & 106.37 & 70 & 67.41 & 10.64 & 1.59 & 67.410 \\
\hline 12 & 00.00 & 00.00 & 11.699 & 5.762 & 80.77 & 70 & 67.41 & 08.08 & 1.59 & 67.410 \\
\hline 13 & 20.60 & 02.36 & 6.918 & 5.762 & 129.32 & 70 & 37.50 & 12.93 & 1.56 & 39.862 \\
\hline 14 & 12.60 & 00.00 & 6.918 & 5.762 & 123.40 & 70 & 39.86 & 12.34 & 1.57 & 39.862 \\
\hline 15 & 05.00 & 00.00 & 6.762 & 5.638 & 80.77 & 70 & 38.12 & 08.08 & 1.59 & 38.124 \\
\hline 16 & 60.55 & 26.33 & 6.762 & 5.638 & 198.80 & 40 & 11.79 & 19.88 & 1.40 & 38.124 \\
\hline 17 & 49.32 & 19.59 & 6.762 & 5.638 & 187.60 & 00 & 18.53 & 18.76 & 1.40 & 38.124 \\
\hline
\end{tabular}

\subsection{Result from the computer models}

In proper scheduling of irrigation, the initial moisture depth $\left(d_{1}\right)$ must be known. The result of the computer model was obtained using equation 2. The values for $I, E_{R F}, E T_{C}, d_{1}$, and $I_{p}$ given in Table1 were substituted into equation 2 to obtain the final soil moisture depth $\left(d_{2}\right)$ for each week. The values of $d_{1}$ used were determined by analyzing the soil moisture for that week. This was done weekly for the entire crop period. The result of the computer model enables one to decide whether to irrigate or not by comparing the result obtained with the values for $d_{\min }$ and $d_{\text {max }}$. However, irrigation was required throughout the whole crop period as it was during the dry season period of the year though the amount of irrigation water applied varied because of some factors like; the degree of cover attained by the crop, rainfall input, evaportranspiration effects e.t.c. Irrigation was applied any time or week the value of $d_{1}$ obtained was less than the minimum allowable limit $(160 \mathrm{~mm})$ for water depletion to augment the situation. The table below is the result of the final moisture depth obtained using equation 2.

Table 2: Final moisture depth obtained using model equation 2

\begin{tabular}{|l|l|l|l|l|l|l|l|l|l|l|l|l|l|l|l|l|l|}
\hline $\begin{array}{l}\mathrm{w} \\
\mathrm{k}\end{array}$ & 1 & 2 & 3 & 4 & 5 & 6 & 7 & 8 & 9 & 10 & 11 & 12 & 13 & 14 & 15 & 16 & 17 \\
\hline $\mathrm{d}$ & $\begin{array}{l}228 . \\
\mathrm{z}\end{array}$ & $\begin{array}{l}179 \\
92\end{array}$ & $\begin{array}{l}148 . \\
75\end{array}$ & $\begin{array}{l}156 . \\
50\end{array}$ & $\begin{array}{l}135 . \\
69\end{array}$ & $\begin{array}{l}120 . \\
07\end{array}$ & $\begin{array}{l}251 . \\
47\end{array}$ & $\begin{array}{l}195 . \\
58\end{array}$ & $\begin{array}{l}219 . \\
15\end{array}$ & $\begin{array}{l}232 . \\
11\end{array}$ & $\begin{array}{l}176 . \\
37\end{array}$ & $\begin{array}{l}150 . \\
77\end{array}$ & $\begin{array}{l}199 . \\
32\end{array}$ & $\begin{array}{l}193 . \\
40\end{array}$ & $\begin{array}{l}150 . \\
77\end{array}$ & $\begin{array}{l}238 . \\
80\end{array}$ & $\begin{array}{l}187 . \\
60\end{array}$ \\
\hline
\end{tabular}

The above result (Table 2) was obtained using equation 2 and input data from Tables 1 . The result showed that $I_{p}$ is an important parameter in scheduling of irrigation water requirement for rice most especially those that grow under pounded condition. Throughout the whole crop period, $d_{2}$ was above the permanent wilting point except for weeks 5 and 6 . During these two weeks, much water is not required in a rice field as it is a short period after transplant because too much water 
may be detrimental to the transplanted crop. The final water level in weeks $3,4,12$ and 15, was below $d_{\min }(160 \mathrm{~mm})$ but not PwP, the crops were not under water stress, since the level of water depletion was above the PwP. Lastly, the table below presents the result of the computer model by Fubara (2006) equation 1.

Table 3: Final moisture depth obtained from equation1 (Fubara, 2006)

\begin{tabular}{|l|l|l|l|l|l|l|l|l|l|l|l|l|l|l|l|l|l|}
\hline $\begin{array}{l}\mathrm{W} \\
\mathrm{k}\end{array}$ & 1 & 2 & 3 & 4 & 5 & 6 & 7 & 8 & 9 & 10 & 11 & 12 & 13 & 14 & 15 & 16 & 17 \\
\hline $\mathrm{d}_{2}$ & $\begin{array}{l}178 . \\
49\end{array}$ & $\begin{array}{l}127 . \\
92\end{array}$ & $\begin{array}{l}98 \\
75\end{array}$ & $\begin{array}{l}86 \\
50\end{array}$ & $\begin{array}{l}65 . \\
69\end{array}$ & $\begin{array}{l}50 . \\
07\end{array}$ & $\begin{array}{l}181 . \\
47\end{array}$ & $\begin{array}{l}125 . \\
58\end{array}$ & $\begin{array}{l}149 . \\
15\end{array}$ & $\begin{array}{l}162 . \\
11\end{array}$ & $\begin{array}{l}106 . \\
37\end{array}$ & $\begin{array}{l}80 . \\
77\end{array}$ & $\begin{array}{l}129 . \\
32\end{array}$ & $\begin{array}{l}123 . \\
40\end{array}$ & $\begin{array}{l}80 . \\
77\end{array}$ & $\begin{array}{l}198 . \\
80\end{array}$ & $\begin{array}{l}187 . \\
60\end{array}$ \\
\hline
\end{tabular}

The above result (Table 3) was obtained using the same input data given in Table 1 but substituted into equation 1 . The values of $d_{2}$ were below the safe allowable limit of water depletion $(160 \mathrm{~mm})$ in all the calculated intervals of time except for weeks $1,7,10,16$ and 17 . It clearly showed that the model equation 1 is unsuitable for the research and that necessitated the modification of that equation. This result strongly indicated that $I_{p}$ is an important parameter which should always be considered in determining the irrigation water requirements for rice, mostly those that are grown under pounded condition. The figure given below (Figure 1) showed the variation in the weekly final moisture depth for the entire period of time. It was plotted using the result of Tables 1 and 2 .

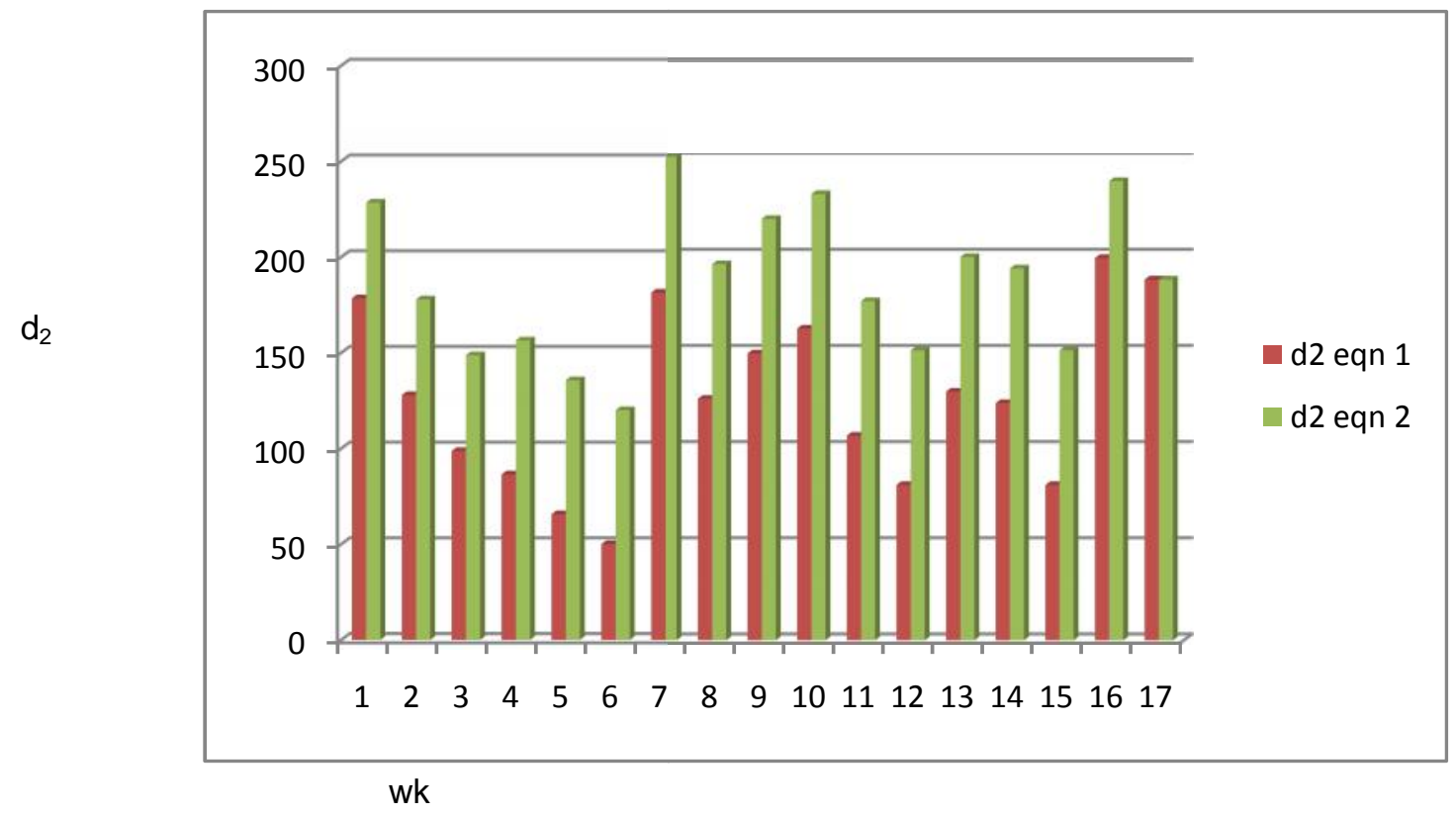

Figure 1: Variations in the final moisture depths obtained using model equations 1 and 2

Figure 1 above showed that the final moisture depth obtained using model equation 1 , were all below the minimum allowable level of moisture depletion except in weeks 1, 7, 10, 16 and 17. This clearly shows that if model equation 1 is adopted for scheduling of irrigation for swamp rice that the crops will be under severe water stress because the irrigation water demand for the crop were not actualized. On the other hand, equation 2 was able to predict the required amount of irrigation water for the same crop except in weeks 5 and 6 . The water need of the 
planted crop at this stage is not much as it is within the early transplant period and too much water at this point can be hazardous to the crop. The values used for the plot are clearly stated in Tables 1 and 2.

\section{CONCLUSION}

This work compared the results obtained from the model of this research with that obtained using the model proposed by Fubara, (2006) using a correlation analytical method. The analysis yielded $r=0.002796$, it simply indicates that there is no linear relationship between the two models and can further be interpreted as the existence of two models that have a wide range of possible dependencies. The poor correlation was due to the impact of the parameter $I_{p}$, which was used in the modification of equation 1 to suit the growth conditions for swamp irrigated rice crop which is not in the mother model. However, the result of Table 2 indicated that the planted rice will be under a very serious water stress if model equation 1 is used in predicting irrigation water requirement for swamp rice. This was clearly shown in the results of Table 3 where the values for $d_{2}$ were all below the minimum value of allowable level of water depletion for the whole period except for weeks $1,7,10.16$ and 17 which was due to the impact of rainfall during those weeks. Irrigation is not essential in week 16 and 17 because the crops have attained full maturity at that stage. Thus, equation 1 cannot be adopted for scheduling of irrigation water requirement for rice. It is best suited for maize and some other crop with similar characteristics which do not grow under pounded condition. Finally, $I_{p}$ is an unavoidable parameter which must be used in any formula, equation or model that could be used in estimating irrigation water requirement for rice especially swamp rice.

\section{ACKNOWLEDGEMENTS}

A big thanks to all the authors cited in this work, Mr Alabi at IITA Ibadan and every other person that assisted in one way or the other. God bless you.

\section{REFERENCES}

Aminul, M. H., Najim, M. M. M and Lee, T. S., 2004. Modeling irrigation water delivery for rice cultivation in east coast Malaysia. Tropical Agricultural Research Paper, 16: $204-213$.
Ayotamuno, M. J., Akor, A. J., Teme, S. C., Essiet, E. W. U., Isirimah, N. O and Idike, F. I., 2000. Relating corn yield to water use during the dry season in Port Harcourt area of, Nigeria. Journal of Agricultural Mechanization in Asia, Africa and Latin America, 31(4):47-51.

Borg, $\mathrm{H}$ and Grimes, D. W., 1986. Depth development of roots with time: An empirical description. Trans. ASAE 29(1): $194-197$.

Brouwer, C and Heibloem, M., 1986. Irrigation water management: Irrigation water needs, Training Manual no. 3. Food and Agricultural Organization of the United Nations, 00100 Rome, Italy.

Counce, P. A., Terry C. K and Andrew, J. M., 2000. A uniform, objective and adaptive system for expressing rice development, Journal of Crop Science, 40:436-443.

Dastane, N. G., 1978. Effective rainfall in irrigated agriculture. Journal of Irrigation and Drainage, FAO, 25: 5-20.

De Delta, S. K., 1973. Principles and practices of rice cultivation under tropical conditions. ASPAC Food Fert. Technol. Cent. Ext. Bu!!. 33. 28.

Doorenbos, J and Pruitt, W. O., 1984. Guideline for predicting crop water requirements. Journal of Irrigation and Drainage paper 24, FAO, Rome, pp.144

FAO, 1986. FAO Corporate Document Repository. Irrigation Water Management: Irrigation Water Needs. Natural Resources Management and Environment Department.

Fubara, M. I., 2006. A mathematical model for estimating the irrigation water schedule for maize in humid tropical environment. PhD. dissertation. Department of Agricultural and Environmental Engineering, Rivers State University of Science and Technology.

Hawksworth, D. L., 1985. Foreword. In S.H. Ou, ed. Rice diseases. CMI Slough, UK, CAB. 380 pp. 
Pearson, K., 1980. Correlation moment product formula

Michael, A. M., 1978. Irrigation: Theory and Practice. Vikas publishing house Pvt Itd. New Delhi, India.

Savage, M. J., Ritchie, J. T., Bland, W. L and Dugas, W. A., 1996. Field measured limits of soil water availability as related to laboratory measured properties. Soil Science Society of American Journals, 47: 770775. ASABE 42: 1609- 1614.

Shah, M. J., 1986. Crop coefficient over rice plain in central plain of Thailand. Field Crops Research, 13:251-256.

Singh, B. N., Maji, A. T., Ng, N. O., Paul, C., Williams, C and Ukwungwu, M. N., 1997. Utilization of Oryza Glaberima genetic resources for lowland rice improvement. International Rice Commission News Letter, Ibadan, Nigeria, WARDA, IITA.

Tamor and O'toole., 1980. Water use in lowland rice Cultivation in Asia: A review of evapotranspiration. Journal of Agricultural Water Management, 3, (2):83-106 .
Tripathy, R. P., 2004. Evapotranspiration and crop coefficients for rice, wheat and pulses under shallow water table condition of Tarai region, Uttaranchal. Journal of Agrometeology, 6(1):17-29.

Tyagi, N. K., Sharma, D. K and Luthra, S. K., 2000. Determination of ET and crop coefficient of rice and sunflower with lysimeter, Journal of Agricultural Water Management 45(1):41-54.

Zhaoyi, L., 1984. A mathematical model for irrigation schedule of rice field. Staff, institute of irrigation studies. University of southern England. 